\title{
The effects of oat bran and soy flour on humoral immune response in rats fed hypercholesterolaemic diets
}

\section{Os efeitos do farelo de aveia e da farinha de soja na resposta imune humoral de ratos alimentados com dieta hipercolesterolêmica}

\author{
Luciana Pereira Lobato ${ }^{1}$, Eduardo Vignoto Fernandes ${ }^{2}$, Luiz Carlos Juliani ${ }^{3}$, Osny Ferrari ${ }^{4}$, \\ Solange de Paula Ramos ${ }^{5}$, Juliana Rubira Gerez ${ }^{6}$, Niara Vanat ${ }^{7}$, Mara Regina Stipp Balarin ${ }^{8}$, \\ Emerson José Venancio ${ }^{9}$, Maria Victoria Eiras Grossmann ${ }^{10}$
}

\begin{abstract}
Previous studies have demonstrated the immunological and hypercholesterolaemic effects of soluble dietary fibre and soy protein in rats. In this study, we evaluated the effects of oat bran and soy flour on humoral immune response in Wistar rats fed hypercholesterolaemic diets. Animals (6 groups) fed with different diets for 6 wks were inoculated twice with antigen (IgY). Plasma samples were collected after each inoculation and anti-IgY antibody (IgM, IgG1 and IgG2a) levels were evaluated by ELISA. Animals receiving 1\% cholesterol presented an increase in anti-IgY IgG1 and a reduction in anti-IgY IgM and IgG2a relative to control animals. These effects were abrogated in animals fed $1 \%$ cholesterol and oat bran or oat bran+soy protein, but not in animals fed $1 \%$ cholesterol and soy protein. Diets containing $1 \%$ cholesterol resulted in hepatic lesions and higher liver and spleen relative weights, but did not affect lipid profile, weight gain, food intake, or food conversion efficiency. In conclusion, a high-cholesterol diet influences classes of antibodies produced in response to an antigen in a way that can be reversed by oat bran.
\end{abstract}

Keyword: $\beta$-glucan. Immunoglobulins. Isoflavones. Soy protein. Wistar rats.

\section{Resumo}

Estudos anteriores têm demonstrado os efeitos sobre o sistema imune e sobre os níveis de colesterol da dieta com fibra solúvel e proteína de soja em ratos. Nesse estudo, nós avaliamos os efeitos do farelo de aveia e da farinha de soja na resposta imune humoral de ratos Wistar tratados com dietas hipercolesterolêmicas. Os animais (6 grupos) foram alimentados com diferentes dietas por 6 semanas e inoculados duas vezes com antígeno (IgY). As amostras de plasma foram coletadas após cada inoculação e os níveis de anticorpos anti-IgY (IgM, IgG1 e IgG2a) foram avaliados por ELISA. Os animais que receberam $1 \%$ de colesterol apresentaram um aumento de IgG1 anti-IgY e uma redução de IgM e IgG2a anti-IgY em relação aos animais controle. Estes efeitos foram anulados em animais alimentados com

\footnotetext{
${ }^{1}$ Doutorado em Ciência de Alimentos pela Universidade Estadual de Londrina. Departamento de Farmácia, Universidade Federal de Sergipe; Lagarto, Sergipe, Brasil. ${ }^{2}$ Doutorado em Patologia Experimental pela Universidade Estadual de Londrina. Departamento de Anatomia, Universidade Estadual de Londrina; Londrina, Paraná, Brasil.. E-mail: eduardovignoto@uel.br

${ }^{3}$ Mestrado em Ciências Biológicas Histologia pela Universidade de São Paulo. Departamento de Histologia, Universidade Estadual de Londrina; Londrina, Paraná, Brasil.

${ }^{4}$ Doutorado em Ciências Biológicas pela Universidade Estadual Paulista “Júlio de Mesquita Filho". Departamento de Medicina Veterinária Preventiva, Universidade Estadual de Londrina; Londrina, Paraná, Brasil.

${ }_{5}^{5}$ Doutorado em Medicina e Ciências da Saúde pela Universidade Estadual de Londrina. Departamento de Histologia, Universidade Estadual de Londrina; Londrina, Paraná, Brasil.

${ }^{6}$ Departamento de Histologia, Universidade Estadual de Londrina; Londrina, Paraná, Brasil.

${ }^{7}$ Departamento de Medicina Veterinária Preventiva, Universidade Estadual de Londrina; Londrina, Paraná, Brasil.

${ }^{8}$ Doutorado em Medicina Veterinária pela Universidade Estadual Paulista "Júlio de Mesquita Filho". Departamento de Medicina Veterinária Preventiva, Universidade Estadual de Londrina; Londrina, Paraná, Brasil.

${ }^{9}$ Doutorado em Ciências Biológicas (Biologia Molecular) pela Universidade de Brasília. Departamento de Ciências Patológicas, Universidade Estadual de Londrina; Londrina, Paraná, Brasil.

${ }^{10}$ Doutorado em Tecnologia de Alimentos pela Universidade Estadual de Campinas. Departamento de Ciência e Tecnologia de Alimentos, Universidade Estadual de Londrina; Londrina, Paraná, Brasil.
} 
$1 \%$ de colesterol e farelo de aveia ou aveia + proteína de soja, mas não em animais alimentados com 1\% de colesterol e proteína de soja. As dietas contendo 1\% de colesterol resultaram em lesões hepáticas e aumentaram o peso relativo do fígado e do baço, mas não afetaram o perfil lipídico, o ganho de peso e o consumo de alimentos ou eficiência na conversão alimentar. Em conclusão, uma dieta com alto teor de colesterol influencia na produção de classes de anticorpos em resposta a um antígeno de forma que pode ser revertida pelo farelo de aveia.

Palavras chave: $\beta$-glucana. Imunoglobulinas. Isoflavonas. Proteína de soja. Ratos Wistar

\section{Introduction}

Several studies have reported the immunological effects of soluble dietary fibre and soy protein (MASILAMANI; WEI; SAMPSON, 2012; WISMAR et al., 2010). The mechanisms by which soluble fibres and soy proteins act on the immune system have not yet been clearly established. The immune activity of dietary fibre has consistently been associated with its subfractions, specifically $\beta$-glucans and mannans (WISMAR et al., 2010). It is likely that the immunomodulatory effects of dietary fibres are related to the modulation of macrophage and dendritic cell activity through carbohydrate-binding receptors on these cells (WISMAR et al., 2010). Soy protein components, such as isoflavones, have well-known chemopreventive and anti-inflammatory activities (MASILAMANI; WEI; SAMPSON, 2012). Furthermore, although soluble fibres and soy protein also have hypercholesterolaemic activities (ALI et al., 2004; DENG, 2009; TONG et al., 2015), the mechanisms by which they lower blood cholesterol and lipid levels have not yet been explained. The cholesterol-lowering activities of dietary fibre and soy protein have been associated with $\beta$-glucan and isoflavones, respectively (ALI et al., 2004; DENG, 2009). Active compounds are normally ingested inside a food matrix and their properties are influenced by the interaction with other components and processing. Thus, studying the effects of such matrices is recommended. Oat-bran is a food rich (approximately $8 \%$ content) in $\beta$-glucan and previous research suggests that $\beta$-glucan may be the most important component in the cholesterol-lowering effect promoted in humans (CHEN; ANDERSON; GOULD, 1981; KIRBY et al., 1981; OTHMAN; MOGHADASIAN; JONES, 2011) and rats (SHINNICK et al., 1988). Oat is also a source of antioxidants, such as tocols and phenolic compounds (ALY, 2012). Soy flour contains, besides proteins (approximately 50\%), other components also associated with lipid lowering properties, such as isoflavones and flavonoids. Balmir et al. (1996) demonstrated the effects of an extract of soy flour on serum cholesterol in rats and hamsters. The aim of this study was to evaluate the effects of oat bran and soy flour on humoral immune response in Wistar rats fed hypercholesterolaemic diets, considering the lack of studies in this field.

\section{Material and Methods}

\section{Animals and diets}

Thirty male Wistar rats (5-wk-old), weighing $145.56 \pm 16.94 \mathrm{~g}$, were maintained at $22 \pm 2^{\circ} \mathrm{C}$ with a 12-h light/dark cycle, and diet and water ad libitum. For $7 \mathrm{~d}$, the rats received a diet prepared according to the recommendations of the American Institute of Nutrition (AIN 93M), following which they were randomly assigned to one of six groups ( $\mathrm{n}=5$ /group) and fed different diets for $45 \mathrm{~d}$. Groups $\mathrm{A}$ and $\mathrm{B}$ were fed diets with the same composition, without cholesterol. The group C diet contained 1\% cholesterol and $0.5 \%$ cholic acid. The diets of groups $\mathrm{D}, \mathrm{E}$, and $\mathrm{F}$ contained cholesterol (1\%), cholic acid $(0.5 \%)$ and tested ingredients. In group $\mathrm{D}$, the protein was replaced by protein from defatted soy flour (Vitao Alimentos, Curitiba, PR, Brazil), in group E, the fibre was replaced by oat bran fibre (SL Alimentos, Mauá da Serra, PR, Brazil), and in group F, all protein and fibre was replaced by a mix of defatted soy flour and oat bran. The diets were prepared by Prag Soluções Biociências (Igarapava, SP, Brazil) and contained similar quantities of protein, lipids, carbohydrates, vitamins, and minerals (Table 1). Body weight and food intake were recorded every week. Food conversion efficiency (FCE) was calculated as the rate of food intake (FI)/total weight gain (WG). The study was approved by the Animal Experimentation Ethics Committee of UEL. 
Table 1 - Composition of diets (AIN 93M and modifications)*.

\begin{tabular}{|c|c|c|c|c|c|c|}
\hline Ingredients & Group A & Group B & Group C & Group D & Group E & Group F \\
\hline & $\begin{array}{l}\operatorname{Ref}_{1(\%)^{\S}}\end{array}$ & $\begin{array}{l}\operatorname{Ref}^{\dagger}(\%)^{\dagger}\end{array}$ & $\begin{array}{l}\text { Control } \\
(\%)^{*}\end{array}$ & Soy (\%) & Oat (\%) & $\begin{array}{l}\text { Soy + Oat } \\
(\%) \#\end{array}$ \\
\hline Oat bran & - & - & - & - & 24.307 & \multirow{2}{*}{27.515} \\
\hline Soy flour & - & - & - & 22.686 & - & \\
\hline Corn starch & 46.57 & 46.57 & 46.57 & 46.57 & 43.063 & 46.450 \\
\hline Casein & 14 & 14 & 14 & 0 & 7.52 & 0 \\
\hline $\begin{array}{l}\text { Dextrinised } \\
\text { starch }\end{array}$ & 15.5 & 15.5 & 15.5 & 15.5 & 15.5 & 15.5 \\
\hline Sucrose & 10 & 10 & 8.5 & 3.698 & 1 & 1 \\
\hline Soy oil & 4 & 4 & 4 & 3.753 & 2.179 & 3.105 \\
\hline $\begin{array}{l}\text { Cellulose } \\
\text { microc }\end{array}$ & 5 & 5 & 5 & 1.363 & 0 & 0 \\
\hline L-cysteine & 0.18 & 0.18 & 0.18 & 0.18 & 0.18 & 0.18 \\
\hline B. colina & 0.25 & 0.25 & 0.25 & 0.25 & 0.25 & 0.25 \\
\hline BHT & 0.0008 & 0.0008 & 0.0008 & 0.0008 & 0.0008 & 0.0008 \\
\hline $\begin{array}{l}\text { Mineral } \\
\text { mix G }\end{array}$ & 3.5 & 3.5 & 3.5 & 3.5 & 3.5 & 3.5 \\
\hline Vitamin mix & 1 & 1 & 1 & 1 & 1 & 1 \\
\hline Cholesterol & --- & --- & 1 & 1 & 1 & 1 \\
\hline Cholic acid & --- & --- & 0.5 & 0.5 & 0.5 & 0.5 \\
\hline
\end{tabular}

*Diets were isoenergetic and given in pellet form. The values are presented on a dry matter basis. §Ref 1 - Group without inoculation of IgY; $†$ Ref 2 - Group with inoculation of IgY; $\$$ Control Group with cholesterol; \#Mix of soy flour (S) and oat bran (O) in the proportions required to achieve total substitution of protein and fibre $(2 \mathrm{~S} \times 2.65$ $+\mathrm{O} \times 1.35$ ).

Source: Authors.

\section{Immunizations and blood collection}

On experimental day 14 , the rats from groups $\mathrm{B}, \mathrm{C}, \mathrm{D}, \mathrm{E}$, and $\mathrm{F}$ were immunized intramuscularly (im) with $100 \mu \mathrm{g}$ of chicken IgY in $100 \mu \mathrm{l}$ of PBS/ Freund's Complete Adjuvant (FCA) (v/v). A second immunization was performed under the same conditions at 35 days, except that the FCA was exchanged for Freund's Incomplete Adjuvant (v/v). The rats in group A (Diet A) were inoculated with PBS/adjuvant only. All animals were sedated by non-lethal inhalation of ethyl ether and approximately $1 \mathrm{ml}$ of blood was collected by cardiac puncture. The collected blood was stored in $1.5 \mathrm{ml}$ plastic tubes containing EDTA ( $2 \mathrm{mg}$ / $\mathrm{ml}$ ) for lipid analysis at 0,15 , and 30 days and for immunological analysis at 14,23 , and 45 days.

The lipid profile was evaluated on the day of collection, whereas the plasma was stored at $-20^{\circ} \mathrm{C}$.

\section{Histological analysis}

Immediately after the final blood collection, the animals were euthanised and their livers processed as previously described by Beçak and Paulete (1970). Histopathological analysis of the liver was performed by three experienced observers who assessed the integrity of hepatocytes and signs of tissue and cell injury in twenty randomly chosen fields. In each field, 8 items were analysed: 1) Preservation of hepatic lobules (arrangement and integrity of the cell strings in relation to the central vein); 2) Integrity of the centrilobular vein; 3) Integrity of the portal space; 4) Congestion and dilatation of hepatic sinusoidal capillaries; 5) Signs of extravasation of red blood cells in the hepatic sinusoids; 6) Integrity of the hepatocyte nuclei (size, coloration and fragmentation); 7) Structure of the hepatocytes; and 8) Fatty infiltration in the cytoplasm of cells.

The criteria used to quantify the degree of possible areas of injury were: 0 , no injury; 1 , mild injury; 2 , moderate injury; 3 , severe injury.

The sum of the indicative signs of injury (absent, mild, moderate, or severe) could have a minimum value of zero, if no indication of injury was found in any of the eight parameters analysed, and a maximum of 24 points if the indicative injuries were maximum in all eight observed parameters. The scores represented the average results of the three observers and were in the ranges 0 (no lesion), 1-8 (mild injury), 9 to 16 (moderate injury), and 17 to 24 (severe injury).

\section{Lipid profile and ELISA}

Lipid profiles were analysed by enzymatic colorimetric procedures for Cholesterol (CHOL) (Cat. 460), HDL (Cat.:413M) and triglycerides (TGs) (Cat.:459) using kits from Gold Analisa Diagnóstica Ltda (Belo Horizonte, MG, Brazil). LDL and VLDL values were calculated as follows: $\mathrm{LDL}=\mathrm{CHOL}-$ $\mathrm{HDL}-\mathrm{TGs} / 5$, and VLDL $=\mathrm{TGs} / 5$.

Plasma levels of IgM, IgG1, and IgG2a were determined by ELISA. Initially, 96-well plates were coated with $10 \mathrm{ng}$ of $\mathrm{IgY}$ in carbonate-bicarbonate $\mathrm{pH}$ 9.6. After incubation for $18 \mathrm{~h}$ at $4^{\circ} \mathrm{C}$, the plates were washed 3 times with PBS-Tween $0.05 \%$. The blocking of nonspecific sites was performed with PBS containing $5 \%$ nonfat milk for $1 \mathrm{~h}$ at $25^{\circ} \mathrm{C}$. After being washed as described above, plasma samples were diluted at 1:500 in PBS containing 1\% nonfat milk and incubated for 
$1 \mathrm{~h}$ at $25^{\circ} \mathrm{C}$. The plates were again washed with PBSTween $0.05 \%$ and the peroxidase-conjugate anti-IgM $(1: 10,000)$, anti-IgG2a $(1: 100,000)$, or anti-IgG1 $(1: 20,000)$ added to the plate and incubated for $1 \mathrm{~h}$ at $25^{\circ} \mathrm{C}$. The plate was washed 3 times with PBS-Tween $0.05 \%$, and substrate solution (sodium acetate buffer

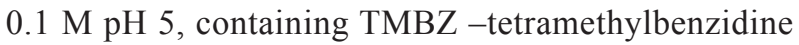
of $1 \%$ and $\mathrm{H}_{2} \mathrm{O}_{2} 0.005 \%$ ) was added. After incubation in the dark for 15 minutes at $25^{\circ} \mathrm{C}$, the reaction was blocked by $1 \mathrm{~N}_{2} \mathrm{SO}_{4}$. Reading was performed in a microplate reader at $450 \mathrm{~nm}$.

\section{Statistical analysis}

Prior to statistical analysis, all data were submitted to the Shapiro-Wilk Normality Test; after which, normal data were analysed by parametric statistical methods and non-normal data were analysed by nonparametric statistical methods. Lipid profile data were compared using the non-parametric Wilcoxon matched pairs signed ranks test for dependent samples and the Kruskal-Wallis test for independent samples. Histological data were compared by the KruskalWallis test followed by Dunn's test. The tissue weight/ rat weight, WG, FI, FCE, and antibody level data were subjected to ANOVA followed by Tukey's test. Data analysis was carried out using Statistica 7.1 with significance set at $\mathrm{P}<0.05$.

\section{Results and Discussion}

No significant differences in initial weights, weight gain, food intake or conversion were observed. The mean initial weight of the rats was $183.5 \pm 0.3 \mathrm{~g}$. At the end of the trial, the rats had gained weight varying from 134.4 to $154.4 \mathrm{~g}$, with a mean food intake of $770.4 \pm 0.8 \mathrm{~g}$ and requiring approximately $5.2 \pm 0.2 \mathrm{~g}$ of each diet to increase one gram in weight. Furthermore, no significant differences were observed in CHOL, LDL, HDL, or TG levels between the groups fed hypercholesterolaemic diets (C, D, E, and F) after 15 days (Table 2). However, an increase from $97.2 \mathrm{mg} /$ $\mathrm{dL}$ to $141.7 \mathrm{mg} / \mathrm{dL}$ in CHOL, $32.9 \mathrm{mg} / \mathrm{dL}$ to $106.2 \mathrm{mg} /$ $\mathrm{dL}$ in LDL-C, and a decrease from $61.3 \mathrm{mg} / \mathrm{dL}$ to 40.2 $\mathrm{mg} / \mathrm{dL}$ in HDL-C were observed in group C.

Data on lipid profile after 30 days is not shown as it seems that there may have been interference with the primary IgY inoculation, occurring 15 days before the third collection. Rats fed diets without cholesterol
Table 2 - Lipid profile of rats exposed to different experimental diets for 15 days**.

\begin{tabular}{|c|c|c|c|c|c|c|}
\hline Variables & Time & $\begin{array}{l}\text { Group } \\
\mathbf{A}^{\S}\end{array}$ & $\begin{array}{l}\text { Group } \\
\mathrm{C}^{\dagger}\end{array}$ & Group D* & $\begin{array}{l}\text { Group } \\
\mathrm{E}^{*}\end{array}$ & $\begin{array}{l}\text { Group } \\
\text { F* }^{*}\end{array}$ \\
\hline \multirow[t]{2}{*}{$\begin{array}{l}\text { CHOL } \\
(\mathrm{mg} / \mathrm{dL})\end{array}$} & Baseline & 91.2 & 97.2 & 100.3 & 101.5 & 100.9 \\
\hline & 15 days & 76.2 & 141.7 & 103.9 & 100.9 & 87.6 \\
\hline \multirow[t]{2}{*}{$\begin{array}{l}\text { LDL-C } \\
(\mathrm{mg} / \mathrm{dL})\end{array}$} & Baseline & 27.7 & 32.9 & 32.0 & 26.2 & 32.2 \\
\hline & 15 days & 17.1 & 106.2 & 92.8 & 76.1 & 51.7 \\
\hline \multirow[t]{2}{*}{$\begin{array}{l}\text { HDL-C } \\
(\mathrm{mg} / \mathrm{dL})\end{array}$} & Baseline & 69.3 & 61.3 & 67.6 & 75.9 & 57.5 \\
\hline & 15 days & 57.8 & 40.2 & 28.6 & 35.7 & 28.1 \\
\hline \multirow[t]{2}{*}{$\begin{array}{l}\text { TG (mg/ } \\
\text { dL) }\end{array}$} & Baseline & 87.5 & 90.8 & 81.9 & 91.4 & 92.1 \\
\hline & 15 days & 80.3 & 82.1 & 102.0 & 103.9 & 103.9 \\
\hline$n$ & & 5 & 5 & 5 & 5 & 5 \\
\hline
\end{tabular}

*CHOL, total cholesterol; HDL-C, high-density lipoprotein cholesterol; LDL-C, low-density lipoprotein cholesterol; TG, triglycerides. §Reference group is represented only by group A (without antigen (IgY) inoculation and without cholesterol). No difference between groups A and B was verified in lipid profile (same diet composition). †Control Group with addition of $1 \%$ cholesterol only. ${ }^{*}$ diets with $1 \%$ cholesterol, $0.5 \%$ cholic acid and tested ingredients (defatted soy flour - group D; oat bran - group E and defatted soy flour plus oat bran - group F). **Values expressed as median.

Source: Authors.

presented significantly lower liver and spleen relative weights (Table 3 ). No difference was observed in the tissue weight/body weight ratio of the thymus and kidney in all treatments.

The histological analysis demonstrated that the rats in all cholesterol intake groups $(\mathrm{C}, \mathrm{D}, \mathrm{E}$, and F) presented significant alterations in liver morphology compared with the rats of groups A and B (Figure 1). In general, the animals of groups $C, D, E$, and $F$ presented moderate injuries while those of groups $\mathrm{A}$ and $\mathrm{B}$ exhibited minor injuries (Figure 2).

Increased levels of anti-IgY IgG1 were observed in immunised animals (groups B, C, D, E, and F) compared to non-immunised animals (group A; Figure 3). Animals from group $B$ also presented an increase in the other anti-IgY antibodies (IgM and $\operatorname{IgG} 2 a$ ). The hypercholesterolaemic diet (group C) promoted an increase in anti-IgY IgG1, compared with control groups $\mathrm{A}$ and $\mathrm{B}$, and a decrease in anti-IgY IgM and $\mathrm{IgG} 2 \mathrm{a}$ in relation to group B. The same effect in anti- 
Table 3 - Tissue to body weight ratios of rats exposed to different experimental diets*.

\begin{tabular}{lllllll}
\hline $\begin{array}{l}\text { Tissue } \\
(\mathrm{mg}) / \\
\text { rat(g) }\end{array}$ & \multicolumn{6}{c}{ Experimental Groups } \\
\cline { 2 - 7 } & Group A & Group B & Group C & Group D & Group E & Group F \\
\cline { 2 - 7 } Liver & $31.1 \pm 2.0^{\mathrm{b}, \mathrm{c}}$ & $5_{6} 7.8 \pm 3.0$ & $42.7 \pm 8.0^{\mathrm{a}}$ & $40.0 \pm 4.0$ & $46.4 \pm 6.0^{\mathrm{a}}$ & $47.3 \pm 2.0^{\mathrm{a}}$ \\
Spleen & $1.9 \pm 0.2^{\mathrm{c}}$ & $1.8 \pm 0.2^{\mathrm{c}}$ & $2 . \mathrm{b}_{\mathrm{c}} 4 \pm 0.5$ & $2.4 \pm 0.4$ & $3.3 \pm 0.8^{\mathrm{a}, \mathrm{b}}$ & $3.0 \pm 0.7^{\mathrm{a}, \mathrm{b}}$ \\
Thymus & $1.3 \pm 0.2$ & $1.0 \pm 0.1$ & $1.3 \pm 0.7$ & $1.1 \pm 0.3$ & $0.9 \pm 0.1$ & $1.0 \pm 0.1$ \\
Kidney & $3.0 \pm 0.3$ & $3.0 \pm 0.2$ & $2.5 \pm 0.7$ & $2.9 \pm 0.1$ & $2.9 \pm 0.2$ & $2.7 \pm 0.2$ \\
\hline
\end{tabular}

* Values expressed as mean $\pm \mathrm{SD}$ and presented in tissue weight/rat weight. Values in the same row followed by different superscript letters are significantly different $(\mathrm{P}<0.05)$.

Source: Authors.

Figure 1 - Histological analysis of livers from rats of different groups (A - F). Groups A and B, diet without cholesterol. Groups $\mathrm{C}$ to F, diets with $1 \%$ cholesterol, $0.5 \%$ cholic acid and tested ingredients (defatted soy flour - group D; fibre of oat bran - group E and defatted soy flour plus fibre of oat bran - group F). The scores represent the average results of three observers and were in the following ranges: 0 (no injury), 1 to 8 (mild injury), 9 to 16 (moderate injury), and 17 to 24 (severe injury). A (*) and B (\#) groups with lower injury scores than other groups $(\mathrm{P}<0.05$, KruskalWallis following Dunn's test).

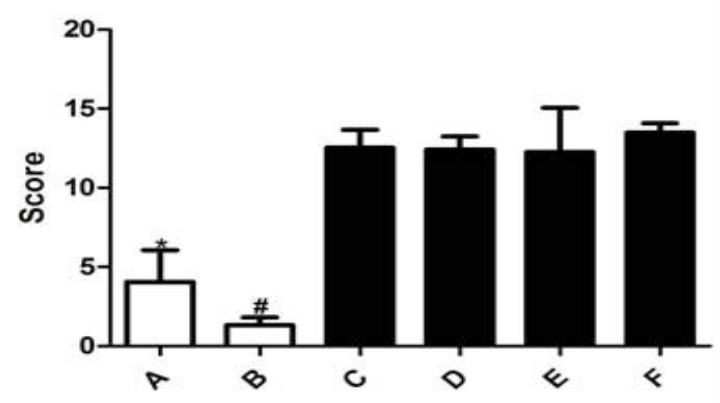

Source: Authors.

$\operatorname{IgY} \operatorname{IgM}$ and $\operatorname{IgG} 1$ was observed for the diet containing cholesterol and soy flour (group D), while animals fed diets containing cholesterol and oat bran (group E) or soy flour/oat bran (group F) had levels of anti-IgY antibodies similar to those in group B and lower antiIgY IgG1 levels compared with group C.

Generally, the consumption of fibre, particularly $\beta$-glucans, provides high satiety, diminishing the food intake and weight gain of animals (KALRA; JOOD, 2000); however, this was not observed in the
Figure 2 - Hepatic portal space of Wistar rats not supplemented $(\mathrm{a}, \mathrm{c})$ and supplemented $(\mathrm{b}, \mathrm{d})$, stained in Hematoxylin and Eosin. a) Hepatic portal space showing normal architecture and portal vein $(\mathrm{P}), 10 \mathrm{X}$ magnification. b) Portal vein (P) and diffuse periportal steatosis with hepatocytes containing a single lipid drop (thick arrow) or multiple lipid inclusions (thin arrows), 10X magnification. c) Normal portal space and portal vein $(\mathrm{P})$ with no inflammatory infiltrate, $40 \mathrm{X}$ magnification. d) Extensive periportal inflammatory infiltrate (yellow arrows) close to portal vein $(\mathrm{P}), 40$ $\mathrm{X}$ magnification.

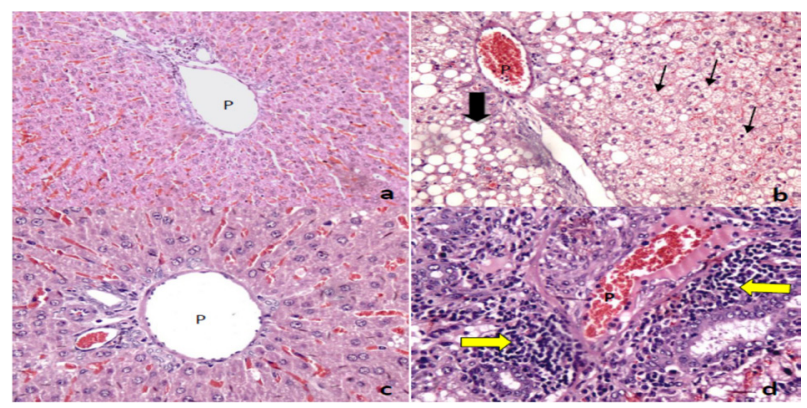

Source: Authors.

current research. The differences in $\beta$-glucan sources, concentration in the diet and interactions with other nutrients can explain the different results. On the other hand, Madani et al. (2004), in a study with Wistar rats fed soybean protein and casein (with or

Figure 3 - Anti-IgY IgM, IgG1 and IgG2a in plasma of rats after 45 days fed with different experimental diets. Groups A and B, diet without cholesterol. Groups C to $\mathrm{F}$, diets with $1 \%$ cholesterol, $0.5 \%$ cholic acid and tested ingredients (defatted soy flour - group D; fibre of oat bran - group E and defatted soy flour plus fibre of oat bran - group F). * Significantly different from group $\mathrm{A} ; * *$ significantly different from group $\mathrm{B} ; * * *$ significantly different from group $\mathrm{C}$; \# significantly different from group $\mathrm{E}(\mathrm{P}<0.05$, ANOVA followed by Tukey's test).

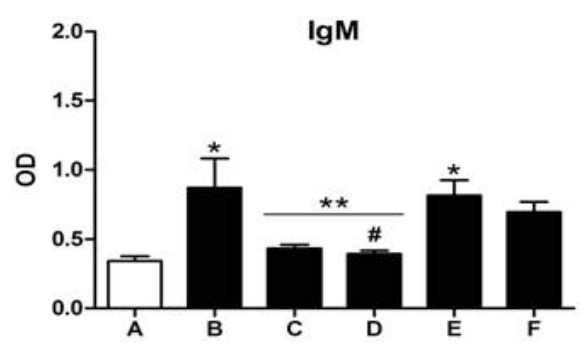


Lobato, L. P.; et al.

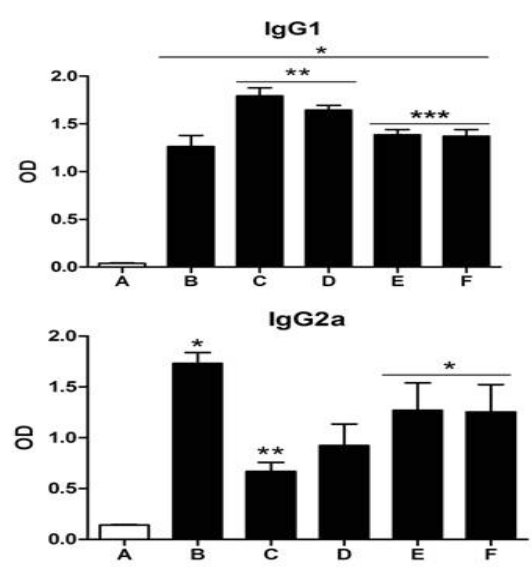

Source: Authors.

without cholesterol) for two months, did not observe differences in food intake of diets containing soy protein, which is in agreement with our results.

The observed increases in CHOL and LDL-C and decreased in HDL-C in group $\mathrm{C}$ (with $1 \%$ cholesterol) demonstrated that the objective of causing modifications in lipid parameters with the addition of $1 \%$ cholesterol and $0.5 \%$ cholic acid in the diets had been achieved, although not reaching hypercholesterolaemia, probably because Wistar rats are not the most suitable animal model for this purpose. While our results showed that soy flour and oat bran have no effect on the lipid profile of rats, Madani et al. (2004) reported no difference in CHOL and TG and a decrease in LDL in rats that consumed soy in comparison with casein (both with cholesterol in the diet), after 2 months of the diet. Ali et al. (2004) showed that isoflavones also reduce total as well as LDL and HDL cholesterol in rats. However, in many studies, a small increase in HDL cholesterol is observed after feeding soybean or isoflavones alone, whereas in others either no change or a small decrease in HDL cholesterol is observed (MASILAMANI; WEI; SAMPSON, 2012). Yamada et al. (1999) related that oral administration of different sources of dietary fibre reduced serum cholesterol levels compared to cellulose feed in rats. The divergence of our results compared with some investigations in the literature may be partially explained by the fact that in some studies active compounds are tested as isolates, in contrast to our study which was developed with oat bran and soy flour. These products contain, in addition to the bioactive compounds targeted in this study, other compounds that may influence physiological responses.

In the present study, we found an increase in the relative liver and spleen weights of rats fed cholesterolcontaining diets (groups C, D, E, and F) compared with rats fed diets without cholesterol (groups $\mathrm{A}$ and B), demonstrating the effects of cholesterol on these organs. Similar results were found by Machado et al. (2003) in Wistar rats fed diets rich in cholesterol. Wistar rats are resistant to the development of hypercholesterolaemia and atherosclerosis due to the high hepatic conversion of cholesterol in bile acids. However, cholesterol consumption causes liver injury in these rats (MACHADO et al., 2003). In the present study, the addition of cholesterol to the diet produced moderate injuries in the liver, and diets containing soy, oats or soy+oats were not sufficient to protect against these injuries. On the other hand, Tong et al. (2014) showed that Wistar rats treated with oat oil for four weeks presented decreased levels of plasma cholesterol concentration; in addition to which, no change was found in weight of the liver. Thus, alterations seen in cholesterol levels and adipose tissues of rats have a straight relationship with the vehicle or form in which the oat is prepared.

In this study, when rats were inoculated with the antigen, an increase in anti-IgY antibody levels was observed only after the second inoculation. Antibody production at the secondary immune response was modulated by a cholesterol-rich diet, as shown by the anti-IgY IgG1 and IgG2a antibody levels in the plasma of animals from group $\mathrm{C}$ (+cholesterol) relative to that of animals from group B (-cholesterol). Furthermore, the consumption of a diet with cholesterol results in high production of the specific antibody IgG1 and low production of IgG2a. In rats, the high IgG1 and IgG2a production in response to an antigen is associated with the cytokines produced by Th2-type lymphocytes (Th2), while $\operatorname{IgG} 2 \mathrm{~b}$ and $\operatorname{IgG} 2 \mathrm{c}$ are associated with interferon- $\gamma$ production by $\mathrm{T}$ helper lymphocytes (Th1) (PEREZ-BEREZO et al., 2011). The Th1 lymphocytes are associated with cellular immune response and resistance to viral and fungal infections, and cancer. Th2 lymphocytes are characterized by their stimulation of the humoral immune response and by their resistance to extracellular microorganisms, such as bacteria. In moderate hypercholesterolaemic mice models, a pro-inflammatory Th1 response has been observed, while in severe hypercholesterolaemia, in an apoE-knockout mice model, the humoral Th2 
response is predominant (ZHOU et al., 1998). In hypercholesterolaemic mice, the Th2 phenotype has been associated with decreased IFN- $\gamma$ expression and macrophage activation, and decreased progression of atherosclerotic lesions (PINDERSKI et al., 2002).

In our study, the effect of cholesterol on IgG1 and IgG2a levels was partially abrogated by diets rich in oat bran (groups E and F), but not by diets rich in soy flour (group D). Oat bran is a food that is rich in fibres; studies have shown that dietary fibres may modulate immunoglobulin (Ig) production. Furthermore, the modulation of Ig production is dependent on the source of the fibre. Lim et al. (1997) observed that IgA levels in the serum of rats fed with guar gum, glucomannan or pectin were significantly higher than those of rats fed cellulose. The IgG level was significantly higher in the glucomannan group than in the group fed guar gum. Similarly, IgM was significantly higher in the glucomannan group than in the group fed cellulose. Dietary fibres may affect Ig production by modulating the expression of GATA-3, an important transcription factor for Th2 response (YE; LIM, 2010). Dietary fibres can modulate Ig production by B lymphocytes indirectly, most likely through their effect on cytokine production by immune cells such as macrophages and dendritic cells (WISMAR et al., 2010). On the other hand, oat bran is a source of $\beta$-glucan, a molecule with anticancer and immunomodulatory activities (HALADOVA et al., 2011; MIZUNO, 1996). The action of $\beta$-glucan in immune cells is dependent on membrane receptors, such as complement receptor 3 and dectin-1, and transcriptional factors such as NF-Kb (BROWN; GORDON, 2001; VOLMAN et al., 2010). Furthermore, dietary oat $\beta$-glucan has been related to an increase in macrophage antiviral resistance and cytokine production by intestinal leukocytes (MURPHY et al., 2009; VOLMAN et al., 2010). In relation to soy protein, Brazilian researchers have shown that soybean is characterized by antioxidant and anti-inflammatory effects in vitro (VERNAZA et al., 2012). However, in the present study, the antiinflammatory action of soybean was not seen in vivo when the animals were submitted to a cholesterol rich diet, in which, after immunization, the antibody production was not increased by treatment with soy.

\section{Conclusions}

Taken together, these results suggest that a diet rich in oat bran can prevent the changes in humoral immunity found in rats fed a cholesterol-rich diet. We can speculate that such effects may be important for the development of new therapeutic strategies for the treatment of diseases associated with hypercholesterolaemia, such as atherosclerosis.

\section{Acknowledgments}

The authors are grateful to SL Alimentos for providing the oat bran and to $\mathrm{CNPq}$ for granting a scholarship to LPL.

\section{References}

ALI, A. A.; VELASQUEZ, M. T.; HANSEN, C. T.; MOHAMED, A. I.; BHATHENA, S. J. Effects of soybean isoflavones, probiotics, and their interactions on lipid metabolism and endocrine system in an animal model of obesity and diabetes. The Journal of Nutritional Biochemistry, Stoneham, v. 15, n. 10, p. 583-590, 2004.

ALY, N. Effect of dietary oat and wheat bran on biochemical changes in rats fed high fat-high cholesterol diets. Journal of Applied Science Research, Faisalabad, v. 8, p. 598-604, 2012.

BALMIR, F.; STAACK, R.; JEFFREY, E.; JIMENEZ, M. D.; WANG, L.; POTTER, S. M. An extract of soy flour influences serum cholesterol and thyroid hormones in rats and hamsters. Journal of Nutrition, Rockville, v. 126, n. 12, p. 3046-3053, 1996.

BEÇAK, W.; PAULETE, J. Técnicas de citologia e histologia. São Paulo: Nobel, 1970.

BROWN, G. D.; GORDON, S. Immune recognition. A new receptor for beta-glucans. Nature, London, v. 413, p. 36-37, 2001.

CHEN, W.; ANDERSON, J.; GOULD, M. Effects of oat bran, oat gum and pectin on lipid metabolism of cholesterol-fed rats. Nutrition Reports International, Los Altos, v. 24, p. 1093-1098, 1981.

DENG, R. Food and food supplements with hypocholesterolemic effects. Recent Patents on Food, Nutrition \& Agriculture, Sharjah, v. 1, n. 1, p. 15-24, 2009. 
HALADOVA, E.; MOJZISOVA, J.; SMRCO, P.; ONDREJKOVA, A.; VOJTEK, B.; PROKES, M.; PETROVOVÁ, E. Immunomodulatory effect of glucan on specific and nonspecific immunity after vaccination in puppies. Acta Veterinaria Hungarica, Budapest, v. 59, n. 1, p. 77-86, 2011.

KALRA, S.; JOOD, S. Effect of dietary barley $\beta$-Glucan on cholesterol and Lipoprotein fractions in rat. Journal of Cereal Science, London, v. 31, p. 141$145,2000$.

KIRBY, R. W.; ANDERSON, J. W.; SIELING, B.; REES, E. D.; CHEN, W. J.; MILLER, R. E.; KAY, R. M. Oat-bran intake selectively lowers serum low-density lipoprotein cholesterol concentrations of hypercholesterolemic men. American Journal of Clinical Nutrition, Bethesda, v. 34, n. 5, p. 824-829, 1981.

LIM, B. O.; YAMADA, K.; NONAKA, M.; KURAMOTO, Y.; HUNG, P.; SUGANO, M. Dietary fibers modulate indices of intestinal immune function in rats. Journal of Nutrition, Springfield, v. 127, p. 663-667, 1997.

MACHADO, D. F.; FERREIRA, C. L. L. F.; COSTA, N. M. B.; OLIVEIRA, T. T. D. Evaluation of the probiotic effect in the modulation of the levels of seric cholesterol and in the weight of the liver of mices fed with rich diet in cholesterol and colic acid. Food Science and Technology, Campinas, v. 23, n. 2, p. 270275, 2003.

MADANI, S.; FRENOUX, J. M.; PROST, J.; BELLEVILLE, J. Changes in serum lipoprotein lipids and their fatty acid compositions and lipid peroxidation in growing rats fed soybean protein versus casein with or without cholesterol. Nutrition, London, v. 20, n. 6, p. 554-563, 2004.

MASILAMANI, M.; WEI, J.; SAMPSON, H. A. Regulation of the immune response by soybean isoflavones. Immunologic Research, Basel, v. 54, n. 1, p. 95-110, 2012.

MIZUNO, T. Development of antitumor polysaccharides from mushroom fungi. Foods \& Food Ingredients Journal of Japan, Tokyo, v. 167, p. 69-85, 1996.
MURPHY, E. A.; DAVIS, J. M.; CARMICHAEL, M. D.; MAYER, E. P.; GHAFFAR, A. Benefits of oat beta-glucan and sucrose feedings on infection and macrophage antiviral resistance following exercise stress. American Journal of Physiology, Bethesda, v. 297, n. 4, p. 1188-1194, 2009.

OTHMAN, R. A.; MOGHADASIAN, M. H.; JONES, P. J. Cholesterol-lowering effects of oat beta-glucan. Nutrition Reviews, Washington, v. 69, n. 6, p. 299-309, 2011.

PEREZ-BEREZO, T.; FRANCH, A.; RAMOSROMERO, S.; CASTELlOTE, C.; PEREZ-CANO, F. J.; CASTELL, M. Cocoa-enriched diets modulate intestinal and systemic humoral immune response in young adult rats. Molecular Nutrition \& Food Research, Weinheim, v. 55, s. 1, p. S56-S66, 2011.

PINDERSKI, L. J.; FISCHBEIN, M. P.; SUBBANAGOUNDER, G.; FISHBEIN, M. C.; KUBO, N.; CHEROUTRE, H.; CURTISS, L. K.; BERLINER, J. A.; BOISVERT, W. A. Overexpression of interleukin-10 by activated $\mathrm{T}$ lymphocytes inhibits atherosclerosis in LDL receptor-deficient Mice by altering lymphocyte and macrophage phenotypes. Circulation Research, Baltimore, v. 90, n. 10, p. 10641071, 2002.

SHINNICK, F. L.; LONGACRE, M. J.; INK, S. L.; MARLETT, J. A. Oat fiber: composition versus physiological function in rats. Journal of Nutrition, Springfield, v. 118, n. 2, p. 144-151, 1988.

TONG, L. T.; ZHONG, K.; LIU, L.; GUO, L.; CAO, L.; ZHOU, S. Oat oil lowers the plasma and liver cholesterol concentrations by promoting the excretion of faecal lipids in hypercholesterolemic rats. Food Chemistry, Barking, v. 142, p. 129-134, 2014.

TONG, L.T.; ZHONG, K.; LIU, L.; ZHOU, X.; QIU, J.; ZHOU, S. Effects of dietary hull-less barley beta-glucan on the cholesterol metabolism of hypercholesterolemic hamsters. Food Chemistry, Barking, v. 169, p. 344-349, 2015.

VERNAZA, M. G.; DIA, V. P.; DE MEJIA, E. G.; CHANG, Y. K. Antioxidant and antiinflammatory properties of germinated and hydrolysed Brazilian soybean flours. Food Chemistry, Barking, v. 134, p. 2217-2225, 2012. 
VOLMAN, J. J.; MENSINK, R. P.; RAMAKERS, J. D.; DE WINTHER, M. P.; CARLSEN, H.; BLOMHOFF, R.; BUURMAN, W. A.; PLAT, J. Dietary (1-->3), (1-->4)-beta-D-glucans from oat activate nuclear factor-kappaB in intestinal leukocytes and enterocytes from mice. Nutrition Research, New York, v. 30, n. 1, p. 40-48, 2010.

WISMAR, R.; BRIX, S.; FROKIAER, H.; LAERKE, H. N. Dietary fibers as immunoregulatory compounds in health and disease. Annals of the New York Academy of Sciences, New York, v. 1190, p. 70-85, 2010.

YAMADA, K.; TOKUNAGA, Y.; IKEDA, A.; OHKURA, K.; MAMIYA, S.; KAKU, S.; SUGANO, M.; TACHIBANA, H. Dietary effect of guar gum and its partially hydrolyzed product on the lipid metabolism and immune function of Sprague-Dawley rats. Bioscience, Biotechnology and Biochemistry, Tokyo, v. 63, p. 2163-2167, 1999.

YE, M. B.; LIM, B. O. Dietary pectin regulates the levels of inflammatory cytokines and immunoglobulins in interleukin-10 knockout mice. Journal of Agricultural and Food Chemistry, Washington, v. 58, n. 21, p. 11281-11286, 2010.

ZHOU, X.; PAULSSON, G.; STEMME, S.; HANSSON, G. K. Hypercholesterolemia is associated with a $\mathrm{T}$ helper (Th) $1 / \mathrm{Th} 2$ switch of the autoimmune response in atherosclerotic apo E-knockout mice. Journal of Clinical Investigation, New Haven, v. 101, n. 8, p. 1717-1725, 1998. 
Lobato, L. P.; et al. 